\title{
Singularidade e identidade nas manifestações de 2013
}

\author{
[ Singularity and identity in the 2013 demonstrations
}

\section{Ricardo Fabrino Mendonça ${ }^{\mathrm{I}}$}

\begin{abstract}
Artigo produzido no âmbito do Projeto "Protestos e engajamento político: discurso e identidade em manifestações contemporâneas”, financiado pelo CNPq (processos 305II7/20I4-9 e 445955/2014-7) e pela Fapemig (APQ-OI206-I5) e que integra ações de uma parceria internacional com pesquisadores da Universidade de Canberra (Austrália) e de uma parceria interinstitucional envolvendo a UFMG, o IESP, a UFES, a UFG e a UFPEL, com financiamento da Capes (Processo: 8888I.I30844/20I6-oI).
\end{abstract}

RESUMO - Este texto busca refletir sobre as noções de singularidade e identidade nas manifestações de 20I3. Partindo do pressuposto de que esses protestos não podem ser compreendidos como movimentos sociais, o artigo examina se, e como, ativistas percebem significados articulados a perpassar suas ações. Teoricamente, o artigo rediscute concepções de identidade a atravessar a literatura sobre ação coletiva e aborda o fortalecimento paradoxal de processos individualizantes derivados de transformações sociais. Interessa ao artigo compreender a força da ideia de singularidade na tessitura contemporânea de vínculos que alicerçam confrontos políticos. Empiricamente, o texto se ancora em 20 entrevistas realizadas com manifestantes de Belo Horizonte que participaram dos protestos de junho de 2013 . A ideia é observar a forma como, ao renarrar o processo, eles compreendem e mobilizam sua inserção e seus vínculos nesse processo político. • PALAVRAS-CHAVE - Identidade coletiva; singularidade; multidão; protestos; Jornadas de
Junho de 20I3. • ABSTRACT - This article aims at discussing the singularity and identity in the 2013 Brazilian demonstrations. Assuming that these demonstrations should nob be considered as social movements, the article examines if, and how, activists make sense of collective meanings pervading their actions. Theoretically, the article explores the notion of collective identity in the literature about collective action and focuses on the paradoxical strengthening of individuation derived from recent social transformations. The article seeks to comprehend the strength of the idea of singularity in the contemporary construction of ties that ground contentious politics. Empirically, the article is based on 20 interviews with activists from the city of Belo Horizonte that have been engaged in the June Journeys (2013). The paper observes how these activists understand their presence and social ties in this political process though their narratives about it. - KEYWORDS - Collective identity; singularity; multitude; protests; 20I3 June Journeys .

Recebido em 23 de setembro de 2016

Aprovado em I8 de abril de 2017

MENDONÇA, Ricardo Fabrino. Singularidade e identidade nas manifestações de 20I3. Revista do Instituto de Estudos Brasileiros, Brasil, n. 66, p. I30-I59, abr. 2017.

DOI: http://dx.doi.org/Io.II6o6/issn.23I6-90IX.voi66pI30-I59

I Universidade Federal de Minas Gerais (UFMG, Belo Horizonte, MG, Brasil). 
Qual a base de uma ação coletiva? O que leva sujeitos diversos não apenas a se agregarem, mas a se verem como parte de algo que os transcende? Como se estruturam e se organizam processos que articulam e vinculam pessoas com ideias, interesses, crenças e valores diferentes? Essas são questões sempre presentes nas múltiplas literaturas que se debruçam sobre conflitos sociais. Seja nos estudos mais clássicos sobre movimentos sociais, seja nas discussões sobre ação coletiva em diversas teorias da justiça, ou em investigações históricas sobre processos de transformação política, a preocupação com a construção de "identidades" entre ativistas mostrou-se central para o avanço da agenda acadêmica dedicada à compreensão dos confrontos políticos.

Essa preocupação vê-se, todavia, renovada na contemporaneidade por três razões. Em primeiro lugar, o conceito de identidade sofreu uma série de críticas por ser visto como restabelecendo uma unidade coerente sob a aparência de questioná-la, ou por negligenciar a necessidade de desidentificação que atravessa conflitos sociais. Em segundo lugar, protestos hodiernos assumem novas faces, colocando em suspeição as organizações hierárquico-burocráticas que conduziram muitas lutas sociais e chamando a atenção para a centralidade de formas mais "individualizadas" de engajamento político. Nesse cenário, movimentos sociais veem-se profundamente reconfigurados ou perdem espaço para outras modalidades de ação coletiva. Em terceiro lugar, vinculado às outras duas razões, nota-se a transformação de modalidades interativas em virtude do crescente uso das tecnologias da informação e da comunicação (TICs), as quais são ora percebidas como geradoras de novas possibilidades para o estabelecimento de vínculos sociais e, consequentemente, de ações coletivas diversas (de flash mobs até ações de crowdfunding), ora entendidas como ameaças individualizantes à construção de capital social.

Nesse contexto, tem aumentado o interesse por compreender a maneira como protestos têm possibilitado a construção de algo "comum" a partir do encontro de uma multiplicidade de singularidades e, simultaneamente, a forma como, em nome de supostas singularidades, essa mesma ideia de comum pode ver-se desconstruída por uma exacerbação do individualismo que esvazia a própria possibilidade da ação coletiva.

Este texto se insere nessa agenda de pesquisa, refletindo sobre as noções de singularidade e coletividade em protestos de 20I3. Partindo do pressuposto de que 
essas manifestações não podem ser compreendidas como movimentos sociais, o artigo examina se, e como, ativistas de Belo Horizonte percebem significados articulados a perpassar suas ações e como compreendem os vínculos a atravessar os ativistas desse processo. Interessa-nos apontar o paradoxal fortalecimento de processos individualizantes na contemporaneidade ${ }^{2}$, evidenciando como esse fenômeno atravessa a percepção sobre o coletivo de ativistas imersos no processo3 ${ }^{3}$.

$\mathrm{O}$ artigo está estruturado em três partes. Na primeira delas, faremos uma discussão dessa literatura que aponta a centralidade do indivíduo em conflitos contemporâneos e alguns dos dilemas gerados por esse fenômeno. Nela, será discutida, ainda, a forma como a noção de multidão, muito em voga na atualidade, vem sendo mobilizada para pensar tal processo, recorrendo a duas tradições mais clássicas de pensamento para entender a articulação entre singular e comum, quais sejam: o pragmatismo norte-americano e o pensamento de Hannah Arendt. Na segunda parte, apresentaremos, brevemente, o contexto dos protestos aqui analisados e a metodologia de nosso estudo de caso, embasado em 20 entrevistas semiestruturadas. Por fim, na terceira parte, discutiremos, a partir das falas dos entrevistados, a tessitura de comunalidades a permear a ação coletiva nas manifestações brasileiras de junho.

\section{Do COLETIVO DE INDIVÍDUOS AO COMUM DE SINGULARES}

A discussão sobre a relação entre indivíduos e grupo em uma ação coletiva é canônica nas ciências sociais, cabendo mencionar, aqui, a clássica discussão de Olson ${ }^{4}$ sobre o problema do free rider e seus desdobramentos na teoria da mobilização de recursos. Nas teorias de movimentos sociais, estudiosos vinculados à teoria do processo político procuraram discutir a forma como enquadramentos e redes preexistentes

2 HONNETH, A. Organized self-realization: some paradoxes of individualization. European Journal of Social Theory, v. 7, n. 4, p. 463-478, 2004; BENNETT, L; SEGERBERG, A. The logic of connective action - digital media and the personalization of contentious politics. Information, communication and society, v. I5, n. 5, p. 739-768, 20I2; BIMBER, B.; FLANAGIN, A.; STOHL, C. Collective action in organizations. New York: Cambridge University Press, 20I2; CARDON, D. A democracia internet - promessas e limites. Rio de Janeiro: Forense, 20I2; CASTELLS, M. Redes de indignação e esperança. Rio de Janeiro: Zahar, 2013.

3 GERBAUDO, P.; TRERÉ, E. In search of the 'we' of social media activism: introduction to the special issue on social media and protest identities. Information, Communication er Society, v. I8, n. 8, p. 865-871, 20I5; MILAN, S. From social movements to cloud protesting: the evolution of collective identity. Information, Communication er Society, v. I8, n. 8, p. 887-900, 2015.

4 OLSON, M. A lógica da ação coletiva: os benefícios públicos e uma teoria dos grupos sociais. São Paulo: Edusp, I999. 
atravessam a estruturação de coletivos 5 . A tradição europeia deu mais ímpeto a essa agenda ao expandir e desenvolver a discussão sobre identidade coletiva, chamando a atenção para sua dinâmica processual e heterogênea, em trabalhos como o de Alberto Melucci ${ }^{6}$. Manuel Castells ${ }^{7}$ também dedicou um livro de sua famosa trilogia para pensar a questão da identidade nas lutas contemporâneas. Como antecipara Jean Cohen ${ }^{8}$, em artigo intitulado "Estratégia e identidade”, uma das grandes contribuições da vertente europeia de pesquisas sobre movimentos sociais era seu foco nos processos de subjetivação e de construção de identidades. Isso teve impacto sobre todo o campo de estudos de movimentos sociais, que passou a devotar mais atenção ao link entre identidade e mobilização?. Um bom exemplo disso é o interessante artigo de David Snow ${ }^{\text {Io }}$ sobre a problemática da identidade, que ressalta a configuração interacional e dinâmica de identidades coletivas no interior de campos discursivos em disputa.

Paralelamente ao núcleo das chamadas teorias dos movimentos sociais, a vertente dos estudos culturais e os pensadores pós-coloniais, em sua interseção com o movimento feminista e com as lutas étnico-raciais e diaspóricas, fortaleceram a discussão sobre identidades, evidenciando seu caráter fragmentado, processual, escorregadio, ambivalente, híbrido e conflitivo. Autores como Stuart Hallir , Paul Gilroy $^{\mathrm{I} 2}$, Homi Bhabha ${ }^{\mathrm{I3}}$, Gayatri Spivak ${ }^{\mathrm{I} 4}$ e Frantz Fanon ${ }^{\mathrm{I5}}$ se inseriram no debate

5 GAMSON, William. Talking politics. Cambridge/Nova York/Melbourne: Cambridge University Press, I992; GAMSON, W. The social psychology of collective action. In: MORRIS, A. D.; MUELLER, C. M. C. Frontiers in social movement theory: New Haven/London: Yale University Press, I992, p. 53-76; FRIEDMAN, Debra; MCADAM, Doug. Collective identity and activism: networks, choices, and the life of a social movement. In: MORRIS, A. D.; MUELLER, C. M. C. Frontiers in social movement theory. New Haven/London: Yale University Press, I992, p. I56-I73; PIVEN, F. F; CLOWARD , R. A. Collective protest: a critique of resource-mobilization theory. In: LYMAN, S. (Ed.). Social movements. Critiques, concepts, case-studies. New York: New York University Press, I995.

6 MELUCCI, A. Challenging codes: collective action in the information age. Cambridge: Cambridge University Press, I996.

7 CASTELLS, M. O poder da identidade. São Paulo: Paz e Terra, I999.

8 COHEN, J. Strategy or identity: new theoretical paradigms and contemporary social movements. Social Research, v. 52, n. 4, p. 663-716, I985.

9 MCADAM, D.; TARROW, S.; TILLY, C. Para mapear o confronto político. Lua Nova, n.76, p. II-48, 2009.

Io SNOW, D. Identity dilemmas, discursive fields, identity work, and mobilization: clarifying the identity-movement nexus. In: STEKELENBURG, Jacquelien van; ROGGEBAND, Conny; KLANDERMANS, Bert. The future of social movement research: dynamics, mechanisms, and processes. University of Minnesota Press, p. 263-280, 2013.

II HALL, S. A identidade cultural na pós-modernidade. 9. ed. Rio de Janeiro: DP\&A, 2004.

I2 GILROY, P. The black Atlantic: modernity and double consciousness. Cambridge, Mass.: Harvard University Press, I993.

I3 BHABHA, H. Nation and narration. London; New York: Routledge, I990

I4 SPIVAK, G. In other worlds: essays in cultural politics. New York: Routledge, I988; SPIVAK, G. Pode o subalterno falar?. Belo Horizonte: Editora UFMG, 20I0.

I5 FANON, Frantz. Black skin white masks. New York: Grove, I967. 
sobre "identidade", ainda que com ressalvas ao conceito, para entender conflitos sociais. As discussões sobre gênero trouxeram novos avanços a essa agenda, com a tentativa de compreender as diferenças a atravessar as mulheres e a questão das interseccionalidades ${ }^{16}$, o debate em torno da construção do sujeito do feminismo ${ }^{17}$, a questão da inclusão em um mundo atravessado por diferenças ${ }^{18} \mathrm{e}$ a desconstrução das identidades ${ }^{19}$. Na visão de Verta Taylor ${ }^{20}$, que também trabalha com gênero, o tema das identidades é quase inescapável, na medida em que a "política é sempre, em certo sentido, sobre identidade". Também no campo da crítica pós-marxista, a reflexão sobre identidade em ações coletivas mostrou-se central, como evidencia a célebre discussão de Laclau e Mouffe ${ }^{2 \mathrm{II}}$ sobre a construção do sujeito revolucionário.

$\mathrm{Na}$ América Latina, García Canclini ${ }^{22}$ e Martín-Barbero ${ }^{23}$ reforçam as discussões sobre a natureza híbrida das identidades e as inserem no debate das mediações. Autores contemporâneos de peso, como Giddens ${ }^{24}$, Gutmann ${ }^{25}$ e Bauman ${ }^{26}$, debatem a dimensão política das identidades. O primeiro desenvolve o conceito de política-vida, alimentada pela reflexividade moderna. Gutmann mostra a centralidade das lutas identitárias para compreender as democracias hodiernas, observando que identidades (socialmente construídas) estruturam as percepções dos sujeitos e permitem a formulação de demandas. E Bauman aborda a questão do pertencimento (e sua fluidez) em tempos marcados pelo questionamento da ideia de um mundo sólido e cristalizado.

Nesta breve e lacunar remissão à centralidade do tema das identidades no interior de agendas sobre confronto político e ação coletiva, interessa-nos, ainda,

I6 hooks, b. Ain't I a woman?: black women and feminism. Boston: South End Press, I98I; CRENSHAW, K. Demarginalizing the intersection of race and sex: a black feminist critique of antidiscrimination doctrine, feminist theory and antiracist politics. University of Chicago Legal Forum, Chicago, v. I40, p. I39-167, I989; COLLINS, P. Fighting words: black women and the search for justice. Minneapolis: University of Minnesota Press, I998; FRASER, N. Multiculturalism and gender equity: the U.S. "Difference" debates revisited. Constellations, v. 3, n. I, p. 6I-72, I996.

I7 COSTA, C. O sujeito no feminismo: revisitando os debates. Cadernos Pagu, v. I9, p. 59-90, 2002.

I8 YOUNG, I. Justice and the politics of difference. Princeton: Princeton University Press, I990.

I9 BUTLER, J. Gender trouble: feminism and the subversion of identity. New York: Routledge, I999.

20 TAYLOR, V. Social movement participation in the global society: identity, networks, and emotions. In: STEKELENBURG, Jacquelien van; ROGGEBAND, Conny; KLANDERMANS, Bert. The future of social movement research: dynamics, mechanisms, and processes. University of Minnesota Press, p. 37-57, 2013, p. 39.

2I LACLAU, E; MOUFFE, C. Hegemony \& socialist strategy: towards a radical democratic politics. London; New York: Verso, I985.

22 GARCÍA CANCLINI, N. Culturas híbridas: estratégias para entrar e sair da modernidade. São Paulo: Edusp, I997.

23 MARTÍN-BARBERO, J. De los medios a las mediaciones: comunicación, cultura y hegemonía. Mexico: G. Gilli, I987.

24 GIDDENS, A. Modernidade e identidade. Rio de Janeiro: Jorge Zahar, 2002.

25 GUTMANN, A. Identity in democracy. Princeton, N. J.: Princeton University Press, 2003.

26 BAUMAN, Z. Comunidade: a busca por segurança no mundo atual. Rio de Janeiro: Jorge Zahar, 2003. 
chamar a atenção para o debate em torno da ideia de reconhecimento, o qual remonta às discussões de Taylor ${ }^{27}$ sobre a configuração narrativa dos selves em um projeto reflexivo. Taylor ${ }^{28}$ propõe pensar lutas por justiça a partir da noção de reconhecimento, lidando com os valores de igualdade e diferença/autenticidade que atravessam os conflitos contemporâneos. Paralelamente, Axel Honneth ${ }^{29}$ propõe uma guinada nas teorias da justiça através do conceito de reconhecimento, que parte da premissa dialógica da formação dos selves para situar a ideia de autorrealização no cerne da definição de justiça. Esse autor discute, ainda, a forma como conflitos sociais demandam o estabelecimento de pontes semânticas entre os sentimentos de indignação experienciados pelos sujeitos para gerar ação coletiva moralmente motivada. Tais ideias provocaram muitas discussões, que buscaram enfatizar a processualidade dinâmica das identidades ${ }^{30}$ e a profunda vinculação entre elas e questões econômico-distributivas ${ }^{31}$.

Para os propósitos deste artigo, é interessante observar, aqui, uma ideia explorada por Honneth ${ }^{32}$ - qual seja, a de paradoxos da individualização-, que aponta que a modernidade gerou uma ruptura importante ao enfatizar a centralidade do indivíduo (e dos processos de racionalização) em seu esforço para defender a crítica, a revisibilidade e o questionamento de tradições e dogmas. Essa ruptura é, contudo, ambivalente, ou paradoxal. Isso porque, por um lado, ela abre espaço para a reflexividade, para a reconfiguração de si e para a construção de identidades coletivas voltadas à promoção de certas pautas. A estruturação de lutas sociais (e dos próprios movimentos sociais) dependeu, em grande medida, da existência de sujeitos críticos em um contexto social no qual as possibilidades de questionar o presente e de projetar o futuro estão colocadas.

Por outro lado, Honneth ${ }^{33}$ percebe que esse mesmo processo de individualização

27 TAYLOR, C. Sources of the self: the making of the modern identity. Cambridge: Harvard University Press, I989

28 recognition. Princeton: Princeton University Press, p. 25-73, I994.

29 HONNETH, A. Luta por reconhecimento: a gramática moral dos conflitos sociais. São Paulo: Ed. 34, 2003.

30 MARKELL, P. Bound by recognition. Princeton: Princeton University Press, 2003.

3I FRASER, N. From distribution to recognition? Dilemmas of justice in a 'postsocialist' age. In: . Justice interruptus - critical reflections on the 'postsocialist' condition. London: Routledge, I997, p. II-39; FRASER, N. Scales of justice: reimagining political space in a globalizing world. New York: Columbia University Press, 2008. Não é interesse deste artigo mapear e detalhar a discussão sobre reconhecimento, ou mesmo marcar posição nesse debate. A essas questões, já nos dedicamos em trabalhos anteriores: MENDONÇA, R. F. Reconhecimento e deliberação: as lutas das pessoas atingidas pela hanseníase em diferentes âmbitos interacionais. 2009. 369f. Tese (Doutorado). Programa de Pós-graduação em Comunicação Social, Universidade Federal de Minas Gerais, 2009; MENDONÇA, R. F. Reconhecimento. In: AVRITZER, L. et al. (Org.). Dimensões políticas da justiça. Rio de Janeiro: Civilização Brasileira, 20I3, p. II7-I3I; MENDONÇA, R. F. What if the forms of recognition contradict each other? The case of the struggles of people affected by leprosy in Brazil. Constellations (Oxford. Print), v. 2I, p. 32-49, 20I4.

32 HONNETH, A., 2004, op. cit.

33 Ibidem. 
alimenta formas de opressão, que impedem a emancipação e o avanço das possibilidades de autorrealização. Em vez de liberdade, nota-se o crescimento de formas sistêmicas de exploração (que responsabilizam indivíduos por sua posição social) e de patologias psicossociais (atreladas ao narcisismo e ao sentimento de vazio em um mundo centrado em biografias individualizadas). Usado como força produtiva (traduzida como iniciativa e flexibilidade), esse individualismo também pode conter a estruturação coletiva de movimentos reivindicatórios. Em um mundo de "eus" autocentrados, isolados e atravessados pela busca meritocrática do sucesso, parece haver pouco espaço para identidades coletivas ${ }^{34}$.

Em trabalho ulterior, Honneth ${ }^{35}$ evidencia que não deseja negar a centralidade de grupos e coletividades na atualidade. Na visão dele, coletividades são essenciais para atualizar laços de reconhecimento intersubjetivo, afirmando valores e normas de que o sujeito depende para se respeitar e se valorizar ${ }^{36}$. No entanto, se ele já apontara os paradoxos da individualização na contemporaneidade, também nota como alguns fatores hodiernos podem contribuir para estabelecer patologias sociais, que oprimem (e reprimem) a individualidade no interior de grupos.

As discussões de Honneth sobre os paradoxos da individualização e sobre o lugar do indivíduo em grupos podem ser relacionadas a alguns estudos atuais sobre a natureza das ações coletivas contemporâneas. Autores como Bennett e Segerberg37, Bimber e seus colaboradores ${ }^{38}$ e Stefania Milan ${ }^{39}$ têm indicado a crescente personalização das lutas sociais, ressaltando a força dos indivíduos nas ações coletivas contemporâneas e a estruturação de grupos, coletividades e organizações que precisam lidar, fortemente com essas individualidades sem ofuscá-las.

Bennett e Segerberg ${ }^{40}$ trabalham com o conceito de ação conectiva para abordar esse processo de transformação. Eles analisam diversos protestos atuais, como os Indignados da Espanha e o Occupy norte-americano, argumentando que a lógica de mobilização e de engajamento dos ativistas seria marcada pela redução de organização em um sentido mais convencional, pela ausência de lideranças claras e pelo incremento de formas de autoexpressão. De acordo com eles, nas sociedades pós-industriais, tem se intensificado uma forma de engajamento com a política pautada pela expressão de esperanças e reivindicações a partir de uma lógica pessoal: "as ideias e os mecanismos para organizar a ação se tornam mais personalizados

34 Note-se que, por um caminho absolutamente diferente e a partir de premissas inteiramente diversas, Honneth chega à mesma questão que, de alguma forma, motivou Olson. OLSON, M., op. cit.

35 HONNETH, A. The I in We: studies in the theory of recognition. Cambridge: Polity, 2012.

36 Ibidem, p. 2 II.

37 BENNETT, L; SEGERBERG, A., 20I2, op. cit.; BENNETT, L.; SEGERBERG, A. The logic of connective action. New

York: Cambridge University Press, 20I3.

38 BIMBER, B.; FLANAGIN, A.; STOHL, C., op. cit.

39 MILAN, S., op. cit.

40 BENNETT, L.; SEGERBERG, A., 20I2, op. cit. 
do que em casos em que a ação é organizada na base de identidade de grupo social, filiação ou ideologia"4I.

Fruto de uma série de transformações sociais que salientam a centralidade do indivíduo, essas formas de ação também se veem alimentadas pela profusão das tecnologias da informação e da comunicação. Tecnologias essas que, como salientam Castells $4^{2}$ e Cardon ${ }^{43}$, têm viabilizado a autocomunicação de massa e a exposição de si. Diferentemente de formas tradicionais de ação coletiva, nessa ação conectiva, fortemente individualizada e tecnologicamente organizada, agir publicamente é uma forma de expressão pessoal e de autovalidação ${ }^{44}$. Para Bennett e Segerberg ${ }^{45}$, essa autoexpressão não significa, todavia, a impossibilidade de uma coletividade. Ao contrário, ela suscita novos tipos de vínculos, que sejam amplos o suficiente para abarcar e incluir diferenças e singularidades. Tais enquadramentos amplos se espalham e atravessam sujeitos, justamente, porque estes se apropriam deles, moldam-nos e os compartilham como seus ${ }^{46}$. É essa adaptabilidade (ou modularidade, nas palavras de Tarrow ${ }^{47}$ ) que os torna potentes.

Esse ponto também é enfatizado por Gerbaudo e Treré $4^{8}$, que organizam um número especial da revista Information, Communication e Society para evidenciar que a força da personalização nos fluxos on-line não implica o fim ou enfraquecimento da relevância do conceito de identidade coletivo. Ao contrário, este se vê alterado e ressignificado, ganhando novos símbolos e mecanismos de construção, como os avatares e memes que Gerbaudo 49 investiga. Há, portanto, alterações nas formas como se constroem coletivos.

Na mesma direção, Bimber, Flanagin e Stohl apontam mudanças estruturais na forma de organização de ações coletivas, sendo que muitas delas operam sem comando organizacional, acordo ideológico ou sentimento de identidade. Eles também ressaltam o fortalecimento das maneiras mais personalizadas de exercício

4I Ibidem, p. 744

42 CASTELLS, M. A galáxia da internet: reflexões sobre internet, negócios e sociedade. Rio de Janeiro: Jorge Zahar, 2003.

43 CARDON, D., op. cit.

44 BENNETT, L.; SEGERBERG, A., 20I2, op. cit., p. 753.

45 Ibidem.

46 Como analisa Paula Sibilia, tornaram-se recorrentes, nas redes sociais, os relatos confessionais, as narrativas sobre experiências e a documentação da presença em certos locais, projetando um "eu" que se coloca diante (e dentro) de um público e de um processo político. Esse "show do eu" para usar o título do livro da autora é característica marcante do contemporâneo. SIBILIA, P. O show do eu: a intimidade como espetáculo. Rio de Janeiro: Nova Fronteira, 2008.

47 TARROW, S. The language of contention - revolutions in words, I688-20I2. Cambridge: University of Cambridge, 20I3.

48 GERBAUDO, P.; TRERÉ, E., op. cit.

49 GERBAUDO, P. Protest avatars as memetic signifiers: political profile pictures and the construction of collective identity on social media in the $20 \mathrm{II}$ protest wave. Information, Communication er Society, v. I8, n. 8, p. 9I6-929, 2015. 
cívico, chamando a atenção para o "contexto contemporâneo, em que cidadãos estão crescentemente acostumados a altos níveis de agência e individualismo ao circular pela sociedade civil e pela esfera pública” ${ }^{\circ}$. Eles ressaltam que as tecnologias não são ferramentas usadas pelos ativistas, mas parte de um contexto mais estrutural (tácito) que ressignifica e altera nossa forma de estar em sociedade. Para os autores, essa alteração está relacionada à fluidez de fronteiras tradicionalmente percebidas como mais rígidas, incluindo as espaciais, as temporais e aquelas que separam público e privado. De acordo com eles, "a redução das fronteiras demanda não apenas uma reconceituação dos princípios da teoria da ação coletiva, mas também sugere que os requisitos para organizar esforços de ação coletiva podem ser cumpridos por um conjunto complexo de arranjos organizacionais"sı. A comunicação entre participantes se torna menos controlada e mais propícia à espontaneidade e à idiossincrasia, sendo que os indivíduos têm mais chances de negociar suas condições de participação. Com isso, a rede de relações e interações que viabiliza o surgimento de uma ação coletiva vê-se alterada em seus pilares fundamentais.

Essas discussões evidenciam a necessidade de compreender formas de ação coletiva contemporâneas que são menos centralizadas e mais atravessadas pela agência e pela expressão dos indivíduos. É exatamente o que busca a ideia de identidades multitudinárias trabalhada por Monterde e colaboradores ${ }^{52} \mathrm{em}_{\text {sua }}$ análise do I5M espanhol. Os autores assinalam que o conceito de multidão, tal como trabalhado por Hardt e Negri, é extremamente útil para compreender a natureza proteiforme e fluida em que níveis individuais e coletivos se articulam na construção desses protestos.

Convém lembrar, aqui, que a discussão de Hardt e Negri53 sobre multidão tem sido muito mobilizada não apenas em pesquisas acadêmicas, mas também na práxis de ativistas. A noção de multidão busca questionar a ideia homogeneizadora e anômica de massa, para reconhecer a centralidade do "singular" na construção do "comum". É preciso deixar claro, de saída, que a díade "singular-comum" não tem equivalência imediata com a díade "indivíduo-coletivo". Justamente por isso, ela joga novas luzes na forma de compreender algumas configurações da ação coletiva na contemporaneidade.

Para os autores, a multidão é uma consequência da sociedade pós-fordista, com suas condições de trabalho flexíveis e abertas, oferecendo-lhe ${ }^{54}$, contudo, uma resistência constante. Como exemplos históricos dessa faceta contestadora

50 BIMBER, B.; FLANAGIN, A.; STOHL, C., op. cit., p. I6.

5 I Ibidem, p. 79.

52 MONTERDE, A.et al. Multitudinous identities: a qualitative and network analysis of the I5M collective identity. Information, Communication er Society, v. I8, n. 8, p. 930-950, 2015.

53 HARDT, M.; NEGRI, A. Multidão: guerra e democracia na era do império. 4. ed. Rio de Janeiro: Record, 20I4. 54 Nota-se, aqui, um ponto de aproximação com a leitura que Honneth faz dos paradoxos de individualização. HONETH, A., 2004, op. cit. No entanto, enquanto este está preocupado em mover-se do potencial emancipatório da individualização para diagnosticar patologias sociais, Hardt e Negri fazem o caminho inverso, começando da patologia, para assinalar o potencial emancipatório. HARDT, M.; NEGRI, A., op. cit. 
da multidão eles citam os protestos de Seattle (I999), o Fórum Social Mundial e a luta do "iQue se vayan todos!" na Argentina. Para Hardt e Negri55, em experiências multitudinárias residiria a capacidade de transformação da realidade, sendo necessário ultrapassar a nostalgia, à la Putnam, de associações tradicionais.

Na definição deles, a multidão é o resultado de interações contínuas entre singularidades que não são harmonizadas, mas que produzem algo em comum. Como o corpo humano ou o cérebro, a multidão produz algo comum a partir da relação entre entidades distintas e irredutíveis umas às outras e não controladas por um único centro. Sua existência depende das (e alimenta as) singularidades. O comum que emerge da interação entre singularidades é produzido por elas, mas também produz algo novo. Ele é a base que permite a própria expressão das singularidades e a criatividade delas derivada. O comum não é, para os autores, sinônimo de público, em sua oposição ao privado. Ele tampouco se insere na dicotomia identidade-diferença. Seu propósito é deslocar ambas as díades, adotando a dupla complementar "partilhasingularidade" 56 . O comum é, como a carne teorizada por Merleau-Ponty, algo que supera os limites do corpo, operando como elemento (semelhante ao ar, à terra, à água e ao fogo) em sua potência incapturável. Sua força política reside na sua dimensão monstruosa, que é a possibilidade de deslocar o estabelecido.

Ainda no que concerne à ideia do comum, é importante recuperar brevemente, aqui, o diálogo com o pragmatismo norte-americano. Hardt e Negri ${ }^{57}$ afirmam que o comum multitudinário opera como o hábito discutido pelos pragmatistas. "O hábito é o comum na prática" 58 . Ele surge de nossas interações e passa a operar tacitamente atravessando nossas vidas. Tal atravessamento não é, todavia, redutor de nossa potência criativa como seres singulares. Ao contrário, o comum é a base a partir da qual criamos. Ele é, como já mencionado, produzido e produtivo. Isso porque, como bem apontam Hardt e Negri, os pragmatistas clássicos não concedem prioridade nem ao individual, nem ao social. Ambos subsistem em uma relação dinâmica de codeterminação.

Hardt e Negri59 buscam, entretanto, desvencilhar sua discussão das noções de comunidade e de público, argumentando que o comum se baseia no encontro de singularidades. É nesse ponto que negligenciam o escopo da contribuição dos pragmatistas. Em Dewey ${ }^{60}$, a comunidade não implica uma unidade preestabelecida nem o apagamento das singularidades. Ao defender a necessidade de que a grande sociedade do início do século XX se reestruturasse como uma grande comunidade, Dewey defende exatamente que era necessário construir uma sociedade democrática capaz de fomentar a formação e a expressão das singularidades. A democracia, como forma de vida, não é um regime de tomada de decisão, mas um projeto coletivo

55 HARDT, M.; NEGRI, A., op. cit.

56 Ibidem, p. 282.

57 Ibidem.

58 Ibidem, p. 257.

59 Ibidem, p. 266.

60 DEWEY, J. The public and its problems. Chicago: The Swallon, I954. 
(comunal) de fomento à autorrealização humana. As preocupações de Dewey, segundo Mendonça,

[...] alimentaram um esforço permanente pela construção de uma sociedade que: assegurasse a liberdade aos indivíduos, sem atomizá-los; fomentasse fins igualitários, sem o uso de meios violentos; e permitisse a autorrealização dos sujeitos, sem promover o anseio pela autoafirmação ${ }^{6 \mathrm{r}}$.

O projeto democrático de Dewey ${ }^{62}$ é voltado, assim, a alimentar as singularidades humanas, ao mesmo tempo que depende delas para se estruturar. Isso porque a comunidade democrática de Dewey se forma por meio da constituição de públicos, os quais refletem, em conjunto, sobre as consequências partilhadas de suas interações. O público, assentado comunicativamente, é a instância mediadora das singularidades para a construção do comum. Ele opera como interface, zona de contato, potência comunicativa. Articula, sem harmonizar, singularidades, criando as condições de possibilidade dessas próprias singularidades. Sem o singular, não há comum, ao mesmo tempo que sem este não há aquele. E, assim como em Hardt e $\mathrm{Negri}^{63}$, para pragmatistas como Dewey, Mead e Hook é a interação comunicativa entre sujeitos que nos dá o mapa para entender tanto o indivíduo, como a sociedade e o processo por meio do qual ambos se transformam.

Neste ponto, é válido remeter, também, e a título de breve menção, à defesa arendtiana da condição necessariamente plural do comum. Em Arendt ${ }^{64}$, a construção do mundo comum requer, fundamentalmente, o encontro ou choque de perspectivas que permanecem singulares e únicas. A metáfora da mesa, empregada pela autora, deixa claro o que ela quer dizer. A mesa é aquilo que, simultaneamente, separa e liga aqueles que nela se dispõem. O mundo comum, como uma mesa, atravessa os sujeitos e os conecta, mas também se interpõe a eles, dividindo-os. O mundo comum depende da diferença, da singularidade, da especificidade. Sem essa pluralidade, derivada da expressão do singular, o comum cessa de existir e, retroativamente, mina as próprias condições de surgimento do singular. A comunicação assegura a visibilidade (a aparência) necessária para esse encontro plural de singularidades que embasa o mundo comum.

A discussão arendtiana sobre a banalidade do mal evidencia com clareza essa questão. Em um contexto totalitário, que solapa individualidades em nome do atomismo massificado, nossos parâmetros comuns de julgamento sobre bem e mal, certo e errado, verdade e mentira perdem força. O comum deixa de existir, assim como as singularidades que eram sua condição de possibilidade e sua consequência

6I MENDONÇA, F. R. Democracia e desigualdade: as contribuições da teoria do reconhecimento. Revista Brasileira de Ciência Política, Brasília, n. 9, p. Ir9-I46, 20I2, p. I23.

62 DEWEY, J. Democracy and education: an introduction to the philosophy of education. New York: The Macmillan, I939; DEWEY, J., I954, op. cit.; DEWEY, J. Liberalismo, liberdade e cultura. São Paulo: Companhia Editora Nacional, I970; DEWEY, J. Individualism - old and new. Amherst: Prometheus books, I999.

63 HARDT, M.; NEGRI, A., op. cit.

64 ARENDT, H. A condição humana. Io. ed. Rio de Janeiro: Forense, 2005. 
permanente. Sem a partilha de singularidades, o comum (que viabilizaria essas mesmas singularidades) fenece.

Essas discussões nos ajudam a refletir sobre a natureza coletiva dos protestos contemporâneos. Se autores como Bennett e Segerberg ${ }^{65}$ e Bimber e colaboradores ${ }^{66}$ são precisos em apontar para uma transformação na forma como a mobilização social e o confronto político se manifestam, entendemos que as ideias pragmatistas oferecem caminhos interessantes. Caminhos esses que não buscam a delimitação de uma identidade coletiva ou de uma organização hierárquica, mas que percebem o processual encontro de singularidades como o alicerce para a construção de comunidades políticas ou públicos distintos das associações tradicionais. Tais comunidades se articulam de formas mais fluidas na promoção de protestos. Desejamos argumentar que as manifestações multitudinárias estabelecem um tipo de comunalidade polifônica e ambivalente, profundamente marcada pela expressão comunicativa de si e pela experiência coletiva dessa expressão. Para subsidiar esse argumento, buscamos fundamento na leitura que alguns ativistas fazem das Jornadas de Junho de 20I3, em Belo Horizonte.

\section{CONTEXTO E PROCEDIMENTOS METODOLÓGICOS}

As Jornadas de Junho de 2013 no Brasil foram uma multiplicidade ambivalente de protestos com um grande número de pessoas em mais de uma centena de municípios do país. Dizemos isso de saída para deixar claro que o nome popularizado para definir o fenômeno que nos interessa (isto é, Jornadas de Junho) é incapaz de apreender sua complexidade. Importante salientar, também de antemão, que não nos interessa aqui precisar o marco inicial desse processo, ou o "verdadeiro" percurso seguido por várias lutas sociais até desaguar no célebre junho. Obviamente, as Jornadas não começaram em junho, nem em 20I3. Nada começa sem articulações com o passado. No entanto, a reconstrução a contrapelo de suas causas e origens faz parte do próprio desdobramento desse processo ${ }^{67}$. Diversas tramas históricas podem ser reconstruídas para reinserir tal acontecimento nas rotinas da continuidade da experiência. Acreditamos que junho de 2013 é um evento singular o suficiente para merecer atenção e ser tratado como tal.

$\mathrm{Na}$ breve narrativa que podemos oferecer aqui, as Jornadas de Junho ganharam força em torno de uma série de protestos em São Paulo contra o aumento do preço das passagens de transportes públicos, puxadas, em um primeiro momento, pelo Movimento Passe Livre. Contribuem fortemente para a assombrosa expansão dessa luta não apenas o histórico recente de reivindicações vinculadas a questões de transporte (e do acesso à cidade, de uma forma mais ampla) em todo o país, mas o contexto internacional de um ciclo de protestos ao redor do mundo e o

65 BENNETT, L.; SEGERBERG, A., 20I3, op. cit.

66 BIMBER, B.; FLANAGIN, A.; STOHL, C., op. cit.

67 MENDONÇA, R. F. et al. Understanding protests as "events" - the symbolic struggles in 2013 protests in

Turkey and Brazil. Article prepared for the 20I6 IPSA meeting. Poznán, 23-28 July 2016. 
contexto nacional da Copa das Confederações, que trouxe grande visibilidade ao Brasil. Ademais, cabe ressaltar o contexto político mais amplo, atravessado por um desgaste do modelo desenvolvimentista no plano nacional e pelo questionamento ao insulamento do governo estadual e da prefeitura municipal. Nesse encontro de fatores, ganha fôlego uma série de protestos que se vê inflamada pela crescente repressão policial. Como resultado, centenas de milhares de pessoas ocupam as ruas da maior cidade do país em uma sequência frenética de protestos que conseguem, dia após dia, travar algumas das principais vias de circulação da cidade em grandes marchas.

Em Belo Horizonte, nota-se uma concentração de pessoas no centro da cidade no dia I3 de junho, como parte da mobilização em torno desse ciclo de protestos ${ }^{68}$. No dia I5, data de abertura da Copa das Confederações, observam-se as primeiras marchas, que rumam a outro local do centro da cidade: a Praça da Estação ${ }^{69}$. A partir de então, uma sucessão de manifestações marca os jogos do Brasil no evento e aqueles realizados no estádio do Mineirão, sendo geralmente compostas por marchas que rumavam ao Estádio do Mineirão, onde aconteciam os jogos de futebol. Além das marchas, a experiência dos protestos na capital mineira é profundamente marcada pela organização da Assembleia Horizontal Popular, que surge como espaço de discussão, planejamento e autogestão ao longo dos protestos ${ }^{70}$.

O processo de Belo Horizonte foi muito atravessado por duas dinâmicas. Em primeiro lugar, um histórico recente de mobilizações políticas, expresso na organização de um coletivo de crítica ao prefeito da cidade (Movimento Fora Lacerda!) e em diversas iniciativas de ocupação de espaços públicos e discussão sobre a utilização deles (movimentos Praia da Estação e Fica Ficus, ocupações culturais, ocupações de movimentos que lutam pela questão da moradia e a emergência de dezenas de blocos carnavalescos na cidade) ${ }^{7 T}$. Essa cena agonístico-cultural foi relevante para a estruturação prévia de redes mobilizadoras mas também para o fortalecimento de outro tipo de relação com a cidade (marcado pela presença das pessoas em espaços públicos) e pela difusão de um ideário de autogestão horizontalizada.

Em segundo lugar, nota-se a força da mobilização anticopa e anti-Fifa na cidade, com as lutas dos vendedores que foram expulsos do entorno do estádio e daqueles que

68 RICCI, R.; ARLEY, P. Nas ruas: a outra política que emergiu em junho de 20I3. Belo Horizonte: Letramento, 20I4; MACHADO, S. Atores políticos em processo: a dinâmica identitária a partir das manifestações de 20I3. Texto apresentado na XXIV Semana do Conhecimento da UFMG, Belo Horizonte, I9-20 de outubro de 2015.

69 FERREIRA, M. A. \#BHNASRUAS: uma análise do confronto político contemporâneo a partir de páginas do Facebook. Dissertação (Mestrado em Ciência Política). Faculdade de Filosofia e Ciências Humanas, Universidade Federal de Minas Gerais, Belo Horizonte, 2015, p. 90.

70 MENDONÇA, R. F.; ERCAN, S. Deliberation and protest: strange bedfellows? Revealing the deliberative potential of 2013 protests in Turkey and Brazil. Policy Studies, v. 36, n. 3, p. 267-282, 2015.

7 RICCI, R.; ARLEY, P., op. cit.; ALBUQUERQUE, C. A. “Ei, polícia, a praia é uma delícia!”: rastros de sentidos nas conexões da Praia da Estação. Dissertação (Mestrado em Comunicação Social). Faculdade de Filosofia e Ciências Humanas, Universidade Federal de Minas Gerais, Belo Horizonte, 20I3; MACHADO, S., op. cit.; FERREIRA, M. A., op. cit. 
se sentiram prejudicados pelas expropriações para a expansão das vias de acesso ao Mineirão, bem como com a estruturação do Copac (Comitê Popular dos Atingidos pela Copa). O Copac-BH foi um dos mais ativos nacionalmente ${ }^{72}$, chegando a organizar (em 20I4) o encontro da Ancop (Associação Nacional dos Comitês Populares da Copa). Os conflitos de maior escala, observados no processo de Belo Horizonte, aconteceram justamente no cruzamento da Avenida Antônio Carlos com a Avenida Abraão Caran, quando manifestantes tentaram adentrar o "território da Fifa", no entorno do estádio.

É a partir da experiência de Belo Horizonte que pensamos a questão da ação coletiva, como discutido na seção anterior. Para realizar nosso estudo, debruçamo-nos sobre 20 entrevistas realizadas com pessoas que participaram desses protestos ${ }^{73}$. A seleção dos entrevistados teve início com um mapeamento inicial de coletivos envolvidos nas manifestações, a partir da literatura existente e de conversas exploratórias. No entanto, também buscamos conversar com algumas pessoas que não se entendiam como integrando coletivos, mas que participaram intensamente dos referidos protestos. A partir desse mapeamento, procuramos a indicação de nomes de pessoas que tinham alguma projeção nos coletivos listados e agendamos as primeiras entrevistas. Ao final de cada entrevista, solicitávamos indicações de pessoas com quem deveríamos conversar, enfatizando a riqueza de escutar pessoas que tivessem opiniões diversas. Empregamos, assim, o procedimento de Snow Ball, a partir de várias entradas, para ampliar o corpus e cobrir diferentes facetas do fenômeno. Interrompemos as entrevistas quando o grau de saturação e redundância se mostrou alto.

As entrevistas foram semiestruturadas e realizadas presencialmente. $\mathrm{O}$ questionário que as orientava estava estruturado em quatro partes: I) sobre o contexto geral dos protestos; 2) sobre os manifestantes; 3) sobre o uso de tecnologias da informação e da comunicação; 4) sobre batalhas simbólicas em torno das manifestações. Na grande maioria das ocasiões, as entrevistas foram conduzidas por dois entrevistadores, sendo que, no total, seis pessoas foram responsáveis pelo conjunto de entrevistas, alternando-se em duplas ${ }^{74}$. Em duas situações, o entrevistado inicialmente indicado solicitou que outras pessoas participassem da entrevista, estruturando-se uma conversa mais coletiva. Não nos opusemos a esse tipo de

72 RICCI, R.; ARLEY, P., op. cit.

73 A pesquisa mais ampla em que se insere esse material, "Protestos e engajamento político", realizou $5 \mathrm{I}$ entrevistas nos municípios de Belo Horizonte e São Paulo. O Projeto "Protestos e engajamento político: discurso e identidade em manifestações contemporâneas”, financiado pelo CNPq (processos 305II7/20I4-9 e 445955/20I4-7) e pela Fapemig (APQ-OI2O6-I5), que integra ações de uma parceria internacional com pesquisadores da Universidade de Canberra (Austrália) e de uma parceria interinstitucional envolvendo a UFMG, o IESP, a UFES, a UFG e a UFPEL, com financiamento da Capes (Processo: 8888I.I30844/20I6-OI).

74 Somos especialmente gratos a Márcia Maria Cruz e Márcio Bustamante pela contribuição na estruturação da coleta de dados e na produção das entrevistas. A Márcia Cruz, também expressamos gratidão por ter embarcado nessa agenda de pesquisa, que será transformada em sua tese de doutorado. Também agradecemos a Davi de Sousa, Selene Machado, Stephanie Reis e Rayza Sarmento pela contribuição no processo de coleta de dados. 
arranjo, embora não o tenhamos incentivado ativamente. Ainda que as entrevistas não tenham pretensões de representar o universo de manifestantes, buscou-se assegurar equidade de gênero, o que demandou, várias vezes, que solicitássemos indicações de mulheres a serem entrevistadas. Ademais, procuramos observar diferenças de classe, conversando com pessoas de coletivos diversos e de origens diferentes, muito embora tenham predominado, em nossa coleta, pessoas de alta escolaridade. Apesar de haver, aqui, um claro viés de seleção, é importante salientar que, segundo pesquisas sobre o perfil dos manifestantes, a maioria dos ativistas tinha elevado grau de escolaridade ${ }^{75}$. Destaca-se, ainda, uma sobrerrepresentação de pessoas que se autodefinem como "de esquerda".

As entrevistas tiveram duração média de 60 minutos, embora algumas delas tenham se estendido por quase três horas e tenha havido algumas mais curtas (em torno de 40 minutos). Uma vez realizadas, as entrevistas foram transcritas. A partir das transcrições, analisamos a forma como os sujeitos percebiam os protestos e sua inserção neles, atentando, especificamente, para a forma como narravam a construção de alguma ideia de coletividade. Interessa-nos compreender, assim, se, e como, sujeitos tão diferentes e com bandeiras tão distintas percebiam-se como partes de algo que os atravessava. Não se trata, obviamente, de buscar uma identidade coletiva das manifestações ou um fator responsável pela coesão da multidão, mas de compreender a maneira como ativistas significam sua presença conjunta em um mesmo processo político. No curto espaço deste artigo, não será possível analisar a complexidade e a variedade de percepções sobre a inserção dos sujeitos nessa ação coletiva, sendo que nos ateremos a algumas questões recorrentes que trazem pistas para entender a relação entre singular e comum nas Jornadas de Junho de 2013. Convém advertir, ainda, que não analisaremos aqui o processo que se segue a esses eventos, em que o caos inicial desse momento ambivalente dá lugar a manifestações mais claramente situáveis no espectro político e mais polarizadas ao longo dos anos de 20I4, 20I5 e 20I6. Embora o acompanhamento longitudinal desse processo nos pareça absolutamente pertinente e interessante, o foco aqui é na ambivalência heterogênea de 2013.

\section{A CONSTRUÇÃo PROCESSUAL E ESPACIAL do COMUM}

A análise das entrevistas aponta para a inexistência de um sentimento de coesão coletiva nas manifestações que seja guiado centralmente por fatores sociodemográficos ou ideológicos. Isso não significa que tais fatores tenham sido irrelevantes nesse processo ou que não atravessaram a construção de identidades coletivas. Muitos grupos e coletivos que compunham o corpo das manifestações (ou a carne, para usar a expressão retomada por Hardt e Negri ${ }^{76}$ ) organizam-se em

75 A pesquisa do Ibope feita no dia 20 de junho de 2013 , com 2.002 entrevistados, assinalou que $43 \%$ dos manifestantes tinha curso superior completo e outros $49 \%$ cursavam o superior ou tinham concluído o ensino médio.

76 HARDT, M.; NEGRI, A., op. cit. 
torno de fatores como raça, gênero, orientação sexual e posicionamento no espectro político-ideológico. Não há dúvidas a esse respeito. No entanto, tais fatores não são amplos o suficiente para abarcar essa multiplicidade constitutiva da multidão, atravessada por muitas tensões e clivagens:

O que fez esses protestos tão ricos como foram foi justamente essa pluralidade, né? Eu não consigo definir uma cara para esses manifestantes dessas passeatas de junho, que essa cara não existe [entrevistada A].

Foi a junção de várias pautas de vários níveis de opressão que geraram aquelas manifestações do ano passado [entrevistado B] ${ }^{77}$.

Os fragmentos sugerem a pluralidade como definidora de algo partilhado. É isso o que faz os protestos serem "tão ricos", agregando milhares de pessoas. Há uma sobreposição de reivindicações distintas que cria algum terreno comum. É preciso ressalvar, ainda, que a questão ideológica, embora muito questionada pela ideia de que tais protestos seriam apartidários, atravessa o discurso dos manifestantes. A recorrência do emprego dos termos esquerda e direita, pelos entrevistados, evidencia que esses não são conceitos superados, mas que se atualizam na organização do espectro político pelos ativistas. Mesmo que sejam mobilizados para apontar diferenças internas a clivar a multidão, tais termos evidenciam a existência de um quadro político mais amplo, partilhado de certa forma pelos manifestantes na maneira de entender aquele processo. Há uma percepção generalizada da natureza política do conflito e de que seria preciso disputá-lo nas ruas, nas redes sociais, nas ocupações, nos debates públicos.

[...] eu acho que a direita ela conseguiu se organizar ao sair do armário, sei lá, explicitar suas pautas [entrevistado $\mathrm{C}$ ].

[...] a principal [batalha simbólica nas manifestações] é direita e esquerda, né? Eu lembro da discussão, até no nosso grupo mesmo, várias discussões de que "ah, a direita perdeu, a esquerda ganhou, a gente conseguiu pautar, a gente conseguiu ir na frente desse grupo" [entrevistada D].

Essa disputa se faz com palavras e gestos, com cores e símbolos, mas fundamentalmente de forma corpórea. Ela aparece, claramente, como instauradora de uma comunalidade, atravessando as diferenças e disputas sem harmonizá-las. Os sujeitos defendiam causas diferentes, agendas distintas, ideologias políticas diversas. Tinham percepções diferentes sobre o cenário político e, muitas vezes, adversários opostos. Partiam de diagnósticos distintos sobre problemas e injustiças e almejavam futuros bastante variados. E, no entanto, caminhavam juntos, partilhando um espaço e um tempo que os retirava da ordem de suas experiências cotidianas. A copresença pública, seja em marchas, seja em ocupações e assembleias, mostrou-se

77 Na transcrição das entrevistas foi mantida a linguagem informal colhida nos depoimentos. 
absolutamente potente na continuidade da mobilização das singularidades em uma ação comum.

É muito recorrente encontrar, entre ativistas desse processo, uma tentativa de explicação de que estavam ali simplesmente porque não podiam ficar de fora. As Jornadas eram grandes demais para que as pessoas pudessem se dar ao luxo de assistir a elas desde seu exterior. Há relatos frequentes entre os entrevistados de uma potência dos processos que atropelava sujeitos e coletivos, dragando-os para a vivência diversa da ação comum. Era preciso fazer parte daquela história, partilhando-a com as demais pessoas, mesmo que não se tivesse clareza do que queriam. Isso porque o que queriam não era tão relevante quanto o fato de estarem na rua, querendo alguma coisa. Essa era a novidade política mais eloquente.

Eu não consegui me segurar no sentido de ficar vendo a banda passar e não fazer nada [entrevistado B].

As manifestações nos atropelaram [entrevistada E].

[...] na hora em que eu cheguei na faculdade e não conseguia parar de ler as notícias, de acompanhar, e aí foi subindo uma ânsia e aí eu falei: "Gente, o Brasil não vai parar a gente... esperar ter.... ah então não é semana de prova, ou ah hoje você trabalha... Não vai esperar férias para gente ter que ir para as ruas protestar. O momento é agora, e já que o povo acordou é agora, a gente tem que ir lá reforçar isso". E aí a gente... em vez de entrar para prova, a gente, eu e minhas amigas, fomos para a papelarias compramos cartaz e fomos para rua. Esse foi o primeiro dia que a gente foi [entrevistada A].

[...] da passarela eu consegui ver toda a manifestação indo, e era gente que não acabava mais. Assim, uma coisa de louco. Eu falei: “Gente, o que que tá acontecendo aqui?”. Foi uma coisa muito surreal. E aí , né, me juntei à massa depois... [entrevistada F].

Eu tava lá por uma questão de empoderamento da população, de achar bom e correto que a população se mostre nas ruas, mostre seu poder, mostre sua voz e não simplesmente ficar formulando pleitos pra um Estado que vai benevolamente atender [entrevistado G].

Os depoimentos indicam a potência de uma experiência coletiva como a de junho de 20I3. O acontecimento histórico se impõe aos sujeitos, afetando-os e retirando-os da continuidade de suas rotinas. O processo político os "atropela" e os empurra "para as ruas protestar". Fundir-se à "massa" é a forma de "não ficar vendo a banda passar", de dar visibilidade ao poder da população. A rua é o local de mostrar esse poder, para além das demandas que surjam dessa demonstração de empoderamento.

A força da partilha do espaço (da rua) se manifesta de forma sutil na insistência que os ativistas entrevistados têm em situar sua ação. São muito recorrentes os relatos detalhados de ações que se balizam, fundamentalmente, em referências espaciais da cidade. Caminhar pela rua $x$, deslocar-se pela avenida $y$, percorrer $z$ quilômetros até a praça $k$ são atividades que mostram a inscrição do sujeito naquela 
ação, vivenciando especificamente algo que não lhe pertence, mas que só existe porque experienciado em comum.

Quando chegamos na Bahia com a Afonso Pena, ao invés de irmos na direção da prefeitura fomos para a Praça Sete. E lá estava acontecendo a dispersão dessa manifestação e engrossamos o caldo por lá. Eu voltei pela Afonso Pena. A caminho de casa, passei em frente à prefeitura, no canteiro central. Vi aquela cena e vi umas pessoas no canteiro central... [entrevistado $\mathrm{H}$ ].

[...] a manifestação que a gente desceu aqui a Antônio Carlos, querendo ir até o Mineirão e quando a gente chegou aqui, na esquina aqui em frente à UFMG, na esquina aqui com a Abrahão Caram... Aí foi um cenário de guerra, né? [entrevistado I].

Da mesma forma que os marcadores espaciais, também as balizas temporais parecem relevantes, na medida em que contribuem para evidenciar essa presença em algo compartilhado com outros sujeitos. Mesmo que os sujeitos não lembrem precisamente o dia de cada manifestação, é muito comum que se esforcem por precisar o dia em que aconteceu esse ou aquele fato.

A primeira reunião foi dia I8, depois foi na segunda-feira. No domingo, tinha tido a primeira grande manifestação que foi até o Mineirão [...] Não foi domingo, foi quarta... foi numa quinta-feira... dia I8, que foi a grande manifestação que foi até ao Mineirão, foi o primeiro jogo realizado aqui em Belo Horizonte [entrevistado $\mathrm{H}$ ].

[...] dia I7, I8, aí dá pra gente ver... 22. Aí tem que olhar... eu não lembro direito a data. A data 26, eu lembro; só do 26 que foi o mais punk. Sábado, dia 26 de junho, e aí a gente vai vendo essa evolução também no registro da imagem, assim [entrevistada $D$ ].

Dia I8 de junho de 2013 foi uma terça-feira. Dia 26 foi uma quarta-feira. Isso não importa. O interessante é perceber os atores, mais de um ano depois das manifestações, a tatear o tempo em busca de pontos de referência que organizem aquele contexto confuso e a sua inserção nele. Contexto em que qualquer dia poderia parecer um sábado para muitos manifestantes. Nota-se, nesses relatos, a forma como espaço e tempo localizam os sujeitos em um fenômeno que transcende a existência individual. Eles parecem operar como base de estabilidade em um processo multitudinário complexo e fragmentado, atravessando as diferenças e especificidades e evidenciando uma partilha corpórea da prática política. São índices de presença, de participação, da vivência concreta daquele período que, de algum modo, existiu para além das balizas espaçotemporais cotidianas.

Essa partilha alicerça a estruturação de algo comum, produzido justamente no encontro daquelas singularidades. É a vivência da partilha (de espaço e de tempo) que estrutura a realização de uma experiência, no sentido deweyano ${ }^{78}$ do conceito. Passar juntos por aqueles protestos, naqueles locais e naqueles momentos é algo que

78 DEWEY, J. Arte como experiência. São Paulo: Martins Fontes, 2010. 
ultrapassa percepções individuais e se instaura como processo coletivo marcado pela acentuação da "vitalidade": "Em vez de encerrar-se em sentimentos e sensações privados, significa uma troca ativa e alerta com o mundo"79. Em uma experiência, sujeitos e meio se atravessam e se modificam. Dão vazão a algo novo, o que pode se manifestar no surgimento de algo coletivo (efêmero, dinâmico e instável).

Ao sentir-se parte de um momento singular, de um evento único, os sujeitos percebem-se atores históricos capazes de afetar o mundo. Se eles "sofrem" junho, no sentido de serem afetados (e "atropelados") por aquele espaço-tempo específico, eles também agem sobre junho e percebem a potência do singular na reconstrução do comunal. Como apontava Dewey: "A própria luta e o conflito podem ser desfrutados, apesar de serem dolorosos, quando vivenciados como um meio para desenvolver uma experiência; fazem parte dela por levarem-na adiante, e não apenas por estarem presentes" ${ }^{\circ \circ}$. Muitos entrevistados explicam que estar presente era uma forma de agir e de levar a experiência adiante.

É constar. É estar lá. É colocar o corpo ali e estar lá... pra estar tão sujeito quanto os outros pra qualquer tipo de abuso policial. Mas fazer número, no sentido de fazer parte. Que o indivíduo pode fazer para garantir que a manifestação vai ser expressiva, que ela não vai ser uma coisa pífia, que não vai chamar atenção nenhuma. Porque a manifestação, em grande parte, ela é a propaganda pelo ato. Ela é um evento de divulgação, ela é uma coisa estética publicitária, então tem que ter um número grande [entrevistado G].

[...] me defrontar com uma experiência de rua tão potente como aquela, do ponto de vista de movimentação de pessoas e de afetos e de gritos, era uma coisa que era magnética. Como não estar ali e como não participar daquilo? [entrevistado J].

Com certeza era um sentimento que eu não consigo explicar, eu chegava nas manifestações eu começava a rir, e eu olhava pra tudo mundo e falava: "Gente, que legal!" sabe? Eu não sei o que que você quer, mas eu sei que você está aqui comigo no mesmo lugar e o sentimento de não pertencimento nos uniu [...]”. Eu chegava nas manifestações e olhava em volta... Eu chorava, porque eu via... Falava assim "véio, eu não conheço ninguém nessa bosta de lugar, mas está todo mundo aqui, olha que doido!” Todo mundo saiu de casa e veio para cá sabendo que isso aqui não tem uma bandeira única [entrevistado K].

Essa experiência de estar na rua, de fazer história, ressignifica o público e adquire diferentes formatos. O corpo na rua acaba por reinventá-la, apontando para possibilidades alternativas de existência social.

79 Ibidem, p. 83.

80 Ibidem, p. п18. 
Estar na rua, estar na cidade, por mais óbvio que seja. [...] É perceber que as pessoas podem simplesmente andar no meio da rua. É um campo de possibilidade que se abre... [entrevistado R].

Eu vejo que a cidade mudou muito a cara de fazer protesto; a cara de se manifestar politicamente, muito por conta dessas brincadeiras que surgiam ali. [...] tinha o Fora Lacerda que parecia mais um bloco de carnaval do que uma marcha onde as pessoas saíam enfileiradas com gritos de guerra [entrevistada L].

Que bom, se a gente puder fazer luta em festa, e fazer festa lutando. Que bom seria se a gente pudesse agregar essas duas dimensões [entrevistado $\mathrm{M}$ ].

A gente tem o BH Mais Amor hoje que foi importantíssimo na eleição aqui em Belo Horizonte, que é um bloco de carnaval que você vai, se diverte, não tem um estatuto, né? [entrevistada P].

Muitas vezes, a ressignificação do espaço público assume tons de festa, irreverência e carnavalização. Busca-se transformar formas de ver e estar em público pela própria vivência partilhada de uma experiência comum. Mafra ${ }^{8 \mathrm{I}}$ lembra que a festa convoca os sujeitos a participar coletiva e corporeamente de uma permanente reconstrução de laços intersubjetivos. De acordo com ele, "uma espécie de 'eletricidade' decorre da aproximação dos indivíduos reunidos em um propósito festivo, que pode levá-los, em poucos instantes, a um grau extraordinário de efervescência" ${ }^{22}$. Em ações coletivas, a dimensão festiva tende a mobilizar sentimental e afetivamente os sujeitos na condição de participantes do processo.

Nem só de festa, contudo, faz-se a experiência comum do espaço público. O corpo na rua também é o corpo que sofre em conjunto a violência, o medo, a angústia e o temor. Como lembram Hardt e Negri ${ }^{83}$, "o cheiro cáustico do gás lacrimogêneo mobiliza os sentidos, e os confrontos de rua com a polícia fazem o sangue ferver de raiva, elevando a intensidade ao ponto de explosão”. Esses sentimentos experienciados coletivamente não são um elemento tangencial do confronto político, conforme nos lembra Calhoun ${ }^{84}$. A vivência conjunta deles contribui para o estabelecimento de alguma relação de solidariedade ou de um sentimento de "nós" - o we-ness, discutido por Melucci ${ }^{85}$ e por Snow ${ }^{86}$ - mesmo em face de diferenças profundas.

8I MAFRA, R. L. M. Entre o espetáculo, a festa e a argumentação: mídia, comunicação estratégica e mobilização social. Belo Horizonte: Autêntica, 2006.

82 Ibidem, p. 65.

83 HARDT, M.; NEGRI, A., op. cit., p. 276.

84 CALHOUN, C. Putting emotions in their place. In: GOODWIN, Jeff; JASPER, James; POLLETTA, Francesca (Ed.). Passionate politics: emotions and social movements. Chicago: University of Chicago Press, 200I, p. $45-57$.

85 MELUCCI, A., op. cit.

86 SNOW, D., op. cit. 
O momento em que me senti mais parte de um grupo, era um grupo de pessoas que estavam à frente... lá na linha de frente mesmo dos conflitos que era um grupo que estava prestando solidariedade [entrevistado $\mathrm{N}$ ].

[...] você está em uma situação em que todo mundo tem um denominador comum, que é estar sendo atacado pela polícia ou estar em uma situação de perigo, e isso cria um vínculo entre as pessoas [entrevistado C].

Quando ocorriam as cenas de horror policial, de repressão que a polícia ia pra cima e soltava bomba [...], eu via muita gente com bandeira do Brasil que antes gritava sem vandalismo e sem violência, colocando a bandeira do Brasil no rosto e pedindo vinagre para ir pra frente, entendeu? [...] Isso tem um valor cabuloso. Essas emoções que surgiram nas Jornadas de Junho porque isso trouxe uma conectividade maior, trouxe um afeto, uma sensação coletiva maior nas pessoas que às vezes compartilhavam emoções, e compartilhavam às vezes até medo, paranoia [...]. A emoção à flor da pele no sentido da gente abraçar o outro e ir pra rua [entrevistado $\mathrm{O}$ ].

De repente, começou a estourar bomba na bateria. E a primeira reação das pessoas foi proteger quem estava carregando instrumento e afastar quem estava carregando os instrumentos. Primeiro, por uma noção de que aqueles instrumentos foram caríssimos para a gente, e a gente tinha que proteger o instrumento. Mas também proteger aquela pessoa que estava ali dando sangue a marcha inteira na bateria [entrevistada P].

Tarrow $^{87}$ explica que esses sentimentos alimentados pela luta são muito importantes no estabelecimento de vínculos entre sujeitos. $\mathrm{O}$ sentimento do medo e da dor, atravessados simultaneamente por ódios e amores partilhados, contribui para o estabelecimento de um sentido de pertencimento e de comunidade, ainda que este possa ser passageiro. Esse comum - construído processualmente ao longo da experiência partilhada do evento - revela uma percepção da natureza coletiva da ação.

Com isso, não se argumenta, aqui, que a copresença seja condição suficiente para a definição de uma ação coletiva, o que expandiria o conceito a ponto de levá-lo à inutilidade. A questão é que, em manifestações multitudinárias dessa natureza, a vivência partilhada de tempo e espaço, da festa e do medo, da alegria e da raiva contribui para o estabelecimento de vínculos muito importantes em contextos de profunda fragmentação de pautas e objetivos. Como advogava Dewey ${ }^{88}$, a percepção da dimensão coletiva de uma experiência é fundadora da possibilidade de públicos que atravessam sujeitos singulares envolvidos em uma ação conjunta. A copresença não precisa ser a consequência de uma identidade coletiva que a precede, mas é, frequentemente, base do coletivo que lhe é simultâneo.

É fundamental ressaltar, ainda e novamente, que esse comum, alimentado pela ação dos sujeitos ao longo das Jornadas de Junho, não elimina a dimensão singular

87 TARROW, S., 2OI3, op. cit.

88 DEWEY, J., I954, op. cit. 
dos indivíduos. O "todo mundo" multitudinário não implica o apagamento de "cada um”, e isso é definidor da própria natureza do "todo mundo". Esse aspecto fica claro na diversidade de gritos, cartazes, agendas e reivindicações vociferadas nos protestos. Fica evidente, também, na multiplicidade de cores (com suas respectivas conotações) portadas pelos corpos ali presentes. Fazem patentes, ainda, nas diferentes táticas, performances e modos de protestar. A ação coletiva que emerge das manifestações de junho de 2013 é profundamente atravessada por singularidades.

Mais que nunca a primeira coisa que as pessoas faziam era se afirmar como indivíduos e se diferenciar no processo. Tipo assim, se individualizar mesmo. Então, os cartazes eram muito isso: a forma como você ia nas manifestações, como você se vestia e tal, isso era uma questão assim que saltava aos olhos. Às vezes, beirava ou chegava mesmo ao hedonismo [...] que era complicada, mas ao mesmo tempo você conseguia tecer identificações entre as pessoas e trazer pessoas para junto assim [entrevistado $\mathrm{C}$ ].

Cada um foi como cidadão, individualmente. E não me identifiquei com nenhum coletivo durante o protesto. Pelo contrário, aqueles coletivos que tentavam se empoderar do protesto, na verdade, mais me afastavam do que atraíam, porque eu acredito que foi o protesto como eu falei... foi justamente essa mobilização espontânea e não uma organização central [entrevistada A].

[...] eu acho que a tendência era de tá ali reunido mesmo, um conjunto muito grande de diferentes subjetividades. Aí, nesse sentido, as pessoas estavam ali mais como elas mesmas, e como que a sua história pessoal, a sua trajetória pessoal levava ela a estar na rua de uma maneira particular [entrevistado Q].

Relatar eventos, postar sobre as manifestações e compartilhar a própria presença nesses atos é um mecanismo de se vincular a eles, agregando-se à multidão. A reunião de subjetividades nos protestos multitudinários fica clara, em alguns casos, na própria maneira como alguns dos entrevistados constroem sua leitura dos protestos. Frequentemente, nota-se um cuidado em dizer o "que me levou para a rua" ou a forma como eu "me organizo":

A pauta que me levou pra rua foi a copa. Aí, com tarifa de ônibus como começou em São Paulo. E, aí, a gente tava mais articulada em torno disso aqui. E aí, quando a gente começa a ir pra rua, vão surgindo outras coisas né, desde a copa até a injustiça da repressão policial e aí vai vários outros processos vão motivando [entrevistada L].

Me organizo enquanto anarquista [entrevistado O].

Em ambas as falas, o coletivo vem puxado pela expressão individual. O indivíduo que se especifica também é aquele que se sente pertencente a alguma espécie de coletivo e que percebe a diversidade de coletivos a compor Junho de 20I3. A própria 
possibilidade do coletivo e a percepção de sua organização estão profundamente vinculadas às agências individuais e à forma como dão sentido ao protesto ${ }^{89}$.

Cabe explicitar aqui que, ao falar dessa diversidade, não se deseja argumentar que essa multidão fosse pacífica, tolerante, amistosa, altruísta ou caridosa. Foram muitos os conflitos entre gritos de "Sem partido" e "Sem fascismo". Em Belo Horizonte, o jargão "Sem violência" foi frequentemente rebatido pela ironia do "Sen-sualiza". Houve diversas formas de atritos, agressões, expressões de preconceito e intolerância ao longo das jornadas. A questão é que isso não contradiz o argumento aqui apresentado, mas o fortalece.

Não se entende as manifestações como um poço de virtudes em que todos são respeitados na construção do bem público. Elas são mais bem compreendidas como um campo disputado por diversas singularidades que, em seus choques e atravessamentos, produzem algo em comum. Comum esse que, como argumentado em outro trabalho, não é necessariamente emancipatório, mas se insere em um processo amplo de deslocamentos da realidade instituída ${ }^{90}$.

O comum que percebemos é diverso, como revelam os próprios conflitos, e essa diversidade foi absolutamente fundamental para gerar a potência e o volume desses protestos. $\mathrm{O}$ tamanho dessas multidões está diretamente vinculado à capacidade delas de encampar, sem harmonizar, o múltiplo e o contraditório. Sem o singular, tais multidões seriam inviáveis e perderiam a própria potência. É a multiplicidade que viabiliza os deslocamentos mútuos na estruturação de algum todo mais complexo.

Como é que eu vou entender o que um homossexual passa? Como que eu vou entender como uma mulher homossexual passa? Não vou. E aí, se eu não tiver disposto a essa troca, a esse compartilhamento e entendimento, realmente nós não temos como construir igualmente e horizontalmente em situação nenhuma [entrevistado S].

Se você fosse para a rua com o objetivo central, um quinto, um décimo, daquelas pessoas não estaria ali, porque existem divergências [entrevistado $\mathrm{K}$ ].

[...] querendo ou não, quem encheu as ruas foram os coxinhas, né? A esquerda sozinha de BH não enche a rua [entrevistado T].

O reconhecimento da incapacidade de ver o mundo pelo olhar dos outros e, por isso, da importância da presença daqueles de quem discordamos parece importante para compreender esse processo. Obviamente, esse reconhecimento nem sempre acontece de imediato, no próprio contato com a diferença, dado o caráter tenso e desestabilizador desses momentos. A reflexividade sobre a potência da alteridade não emerge, necessariamente, e a todo momento, no ato dos protestos. $\mathrm{O}$ ponto, aqui, todavia, é que as manifestações abrem brechas para esse tipo de reflexividade.

89 BIMBER, B.; FLANAGIN, A.; STOHL, C., op. cit.; BENNETT, L.; SEGERBERG, A., 20I3, op. cit.

90 SARMENTO, R.; REIS, S.; MENDONÇA, R. F. As jornadas de junho e a questão de gênero: as idas e vindas das lutas por justiça. Revista Brasileira de Ciência Política, n. 22, p. 93-I28, 2017. 
Note-se, por exemplo, a fala que, de forma ambivalente, salienta o papel dos chamados “coxinhas" nas manifestações ${ }^{91}$.

A fala também deixa claro, contudo, que reconhecer a multiplicidade não implica ampla concordância com tudo o que as singularidades expressam. Implica, ao contrário, reconhecer o lugar dos conflitos que atravessam essa ação coletiva, o que conduz os atores a se engajarem em várias disputas simbólicas e a construírem seus próprios grupos no interior da ação coletiva mais ampla em que se inserem.

Eu tive uma sensação de que as pessoas tentavam procurar os iguais, os similares, os parecidos, e organizar, tentar sair em grupo assim para até ter uma segurança ali de com quem você está andando, o que que está acontecendo [entrevistada D].

[...] tem uma identidade visual mínima, com faixa, bandeira e vestimenta, e dentro da manifestação, da marcha andar em grupo, tanto por questões de segurança, mas como também pra mostrar a expressividade da bandeira [entrevistado G].

[...] teve um momento em que eu me descolei assim dos meus amigos e me vi numa manifestação meio contrária ao que eu acredito assim, né, o pessoal cantando o hino nacional e reivindicando pátria, nacionalismo. É... "sou brasileiro, com muito orgulho, com muito amor", bandeira do Brasil, e aí, nessa hora, eu tava sozinha, olhei pro lado e falei: “Gente, eu tô na marcha da família com Deus pela liberdade”. Ai falei: “ó, deixa eu sair daqui”, aí fui andando mais na frente, aí achei uns amigos, aí, tipo assim ah "ufa”, né? [entrevistada F].

O último fragmento menciona um corte fundamental na organização dos subgrupos dentro de muitas manifestações, evidenciando a multiplicidade das Jornadas de Junho: o patriotismo. $\mathrm{O}$ amor à nação foi um importante aglutinador de sujeitos ao mesmo tempo que era rechaçado por muitos outros.

9I “Coxinha" é o termo pejorativo que se tornou recorrente a partir das Jornadas de Junho para se referir, geralmente, a sujeitos historicamente pouco engajados em reivindicações políticas e que começaram a se manifestar em clara oposição a discursos tidos como "de esquerda", de uma forma geral, e ao "petismo", de forma mais específica. As origens da expressão são controversas, mas antecedem as Jornadas de Junho. Ela é frequentemente atrelada, de forma irônica, a policiais militares no estado de São Paulo, seja pelo valor reduzido do auxílio refeição desses profissionais (o que só lhes possibilitaria comprar um salgado), seja pela suposta prática de comerem coxinhas em lanchonetes e padarias em troca de proteção local. Em Belo Horizonte, o termo adquiriu nova camada de sentido, visto que, em 20I2, o vereador que, à época, presidia a Câmara Municipal foi acusado de ter utilizado mais de 60 mil reais de verbas indenizatórias na compra de lanches fornecidos pela empresa de sua madrasta. Um jornal local fez a comparação do número de "coxinhas" que poderiam ser compradas pelo valor, e uma série de piadas celebrizou o episódio. No carnaval de 20I2, uma marchinha inspirada no caso (intitulada "Na coxinha da madrasta") venceu uma competição local e tornou-se hit na cidade. Muitos manifestantes entrevistados lembram esse episódio ao remeter ao termo "coxinha". 
[...] foi um momento muito emocionante, assim, enquanto brasileira, eu lembro que a gente ia cantando o hino na Antônio Carlos, nossa! É uma das lembranças mais emocionantes de Brasil que eu tenho, um tanto de gente diferente, assim, só rosto diferente, grupo diferente, todo mundo ali; aquele sentimento de Brasil ficou muito forte, né? [...] Eu tava ali pelo Brasil, não era por um partido, por uma ideologia específica, é pelo Brasil [entrevistada A].

[...] é uma galera que saiu pela mídia e colocou bandeiras do Brasil, achando que colocando bandeira do Brasil seria revolucionário, super-rebelde, quando na realidade você está colocando uma bandeira totalmente conservadora e positivista de um pátria racista, homofóbica, machista [entrevistado O].

[...] tinha a marcha desse bloco da esquerda, mas tinha uma ala mais voltada com bandeiras do Brasil [entrevistado R].

[...] vou de verde e amarelo em uma ou duas manifestações, e eu não acho problema algum nesse sentido. E acho que quando a gente nega isso "sai daqui que você é coxinha”... a gente está negando a possibilidade de trazer pessoas que podem estar do nosso lado [entrevistado B].

As falas evidenciam a dimensão agonística que atravessa essas ações coletivas. A pátria é vista, por alguns, como o signo suprapartidário que estabeleceria um denominador comum, mas também, por outros, como o divisor a marcar claramente as contradições daquele processo histórico. Aos moldes arendtianos, a pluralidade do comum se desdobra em narrativas conflitantes, incapazes de domar a expressão do singular. E é justamente por isso que se reconhece a dificuldade de construir formas de organização política afinadas com essa forma de agência coletiva: "não tem quem apresente hoje uma alternativa de organização que caiba no momento histórico que a gente vive. Tem várias organizações tentando [entrevistada P]”.

Organizar esse comum que emerge da partilha tensa e agonística de singularidades pode implicar seu próprio enfraquecimento. Sua potência e seus perigos residem na sua ambivalência carnavalesca, para lembrar a expressão bakhtiniana92. O comum dessas manifestações é desestabilizador em sua “incapturabilidade”. Ele reabre um contexto de politização e de disputas que convoca os seres humanos a se lembrarem de que o futuro não está pronto, e que ele pode caminhar em direções muito diversas. O comum que insiste no encontro das singularidades é o comum que acena para a contingência do presente, para a multiplicidade efêmera das categorias definidoras dos sujeitos sociais e para a necessidade do político.

92 BAKHTIN, M. M. A cultura popular na Idade Média e no Renascimento: o contexto de Francois Rabelais. 5. ed.

São Paulo: Hucitec, 2002. 


\section{CONSIDERAÇõES FINAIS}

O presente artigo buscou discutir a dimensão coletiva de protestos multitudinários contemporâneos a partir de um estudo de caso sobre as Jornadas de Junho de 2013 em Belo Horizonte. O objetivo foi o de apontar para a possibilidade de estruturação de vínculos e articulações em um cenário profundamente marcado pela acentuação dos processos de individualização.

Para tanto, realizamos um percurso teórico que partiu das discussões sobre identidade e ação coletiva, adentrou debates contemporâneos sobre os paradoxos da individuação, abordou o incremento no uso de quadros personalizados em conflitos políticos e chegou à discussão sobre a articulação de singularidades na produção de um comum. Nesse último aspecto, exploramos a maneira como Hardt e Negri93 desenvolvem o conceito de multidão para argumentar que eles fornecem insights interessantes para a compreensão do fenômeno que nos interessa, muito embora se desvinculem rápido demais dos conceitos de comunidade e de público, que são devidamente tratados pelo pragmatismo norte-americano de base deweyana. Além disso, buscamos resgatar a centralidade do pensamento arendtiano na discussão sobre a produção pública do mundo comum a partir do encontro de singularidades.

Com base nessas ideias, exploramos 20 entrevistas realizadas com pessoas que participaram das Jornadas de Junho em Belo Horizonte. A análise procurou elucidar como esses sujeitos, na condição de participantes, perceberam sua inserção nas manifestações e suas articulações a outros sujeitos. O estudo revelou a centralidade da experiência comum para a geração de um sentido de coletividade, que embasa uma configuração efêmera de público. É na vivência coletiva do espaço e do tempo, do medo e dos afetos, da violência e da festa que os sujeitos alimentam a potência de um público que se sente parte de um comum, ainda que, ou justamente porque, profundamente atravessado pelas diferenças.

O comum das manifestações, o coletivo que surge desse encontro de singularidades, é plural, conflituoso e agonístico. Ele evidencia sua multiplicidade em cores, debates, tensões e polarizações. Ele abarca o patriotismo e o antinacionalismo, as expressões de causas individuais e as lutas de grupos e coletivos, os defensores de certos partidos e aqueles que gritam por uma coletividade antipartidária. Os entrevistados narram o tatear coletivo por formas de lidar com essa organização, a ansiedade em perceber certas diferenças e a surpresa de ver-se similar ao radicalmente distinto. Ao fazê-lo, evidenciam a potência política dessa comunidade efêmera e tensa, que se torna um público, por meio de uma experiência que abre possibilidades para uma ressignificação e reconstrução do mundo. A multidão de junho é tensa, ambivalente, conflituosa, contraditória e potente, como os públicos vislumbrados por Dewey ou as singularidades que alimentam o mundo comum arendtiano. É dessa ambivalência que surgem fios muito distintos a tecer processos políticos nos anos que se seguiram a 20I3. Fios esses que parecem guardar, simultaneamente, potências emancipatórias e ameaças à própria democracia, mas nunca apenas uma dessas dimensões.

HARDT, M.; NEGRI, A., op. cit. 


\section{SOBRE O AUTOR}

RICARDO FABRINO MENDONÇA é professor do Departamento de Ciência Política da UFMG. Bolsista de produtividade do CNPq. É coordenador do Margem Grupo de pesquisa em Democracia e Justiça e membro do INCT em Democracia Digital.

E-mail: ricardofabrino@hotmail.com

\section{REFERÊNCIAS BIBLIOGRÁFICAS}

ALBUQUERQUE, C. A. “Ei, polícia, a praia é uma delícia!”: rastros de sentidos nas conexões da Praia da Estação. Dissertação (Mestrado em Comunicação Social). Faculdade de Filosofia e Ciências Humanas, Universidade Federal de Minas Gerais, Belo Horizonte, 2013.

ARENDT, H. A condição humana. Io. ed. Rio de Janeiro: Forense, 2005.

BAUMAN, Z. Comunidade: a busca por segurança no mundo atual. Rio de Janeiro: Jorge Zahar, 2003.

BAKHTIN, M. M. A cultura popular na Idade Média e no Renascimento: o contexto de Francois Rabelais. 5. ed. São Paulo: Hucitec, 2002.

BENNETT, L.; SEGERBERG, A. The logic of connective action - digital media and the personalization of contentious politics. Information, communication and society, v. I5, n. 5, p. 739-768, 2012.

BENNETT, L.; SEGERBERG, A. The logic of connective action. New York: Cambridge University Press, 20I3. BHABHA, H. Nation and narration. London; New York: Routledge, I990

BIMBER, B.; FLANAGIN, A.; STOHL, C. Collective action in organizations. New York: Cambridge University Press, 2012.

BUTLER, J. Gender trouble: feminism and the subversion of identity. New York: Routledge, I999.

CALHOUN, C. Putting emotions in their place. In: GOODWIN, Jeff; JASPER, James; POLLETTA, Francesca (Ed.). Passionate politics: emotions and social movements. Chicago: University of Chicago Press, 200I, p. 45-57.

CARDON, D. A democracia internet - promessas e limites. Rio de Janeiro: Forense, 2012.

CASTELLS, M. O poder da identidade. São Paulo: Paz e Terra, I999.

. A galáxia da internet: reflexões sobre internet, negócios e sociedade. Rio de Janeiro: Jorge Zahar, 2003.

. Redes de indignação e esperança. Rio de Janeiro: Zahar, 2013.

COHEN, J. Strategy or identity: new theoretical paradigms and contemporary social movements. Social Research, v. 52, n. 4, p. 663-7I6, I985.

COLLINS, P. Fighting words: black women and the search for justice. Minneapolis: University of Minnesota Press, I998.

COSTA, C. O sujeito no feminismo: revisitando os debates. Cadernos Pagu, v. I9, p. 59-90, 2002.

CRENSHAW, K. Demarginalizing the intersection of race and sex: a black feminist critique of antidiscrimination doctrine, feminist theory and antiracist politics. University of Chicago Legal Forum, Chicago, v. I40, pp. I39-I67, I989. 
DEWEY, J. Democracy and education: an introduction to the philosophy of education. New York: The Macmillan, I939.

. The public and its problems. Chicago: The Swallon, I954.

. Liberalismo, liberdade e cultura. São Paulo: Companhia Editora Nacional, I970.

. Individualism - old and new. Amherst: Prometheus books, I999.

. Arte como experiência. São Paulo: Martins Fontes, 2010.

FANON, Frantz. Black skin white masks. New York: Grove, I967.

FERREIRA, M. A. \#BHNASRUAS: uma análise do confronto político contemporâneo a partir de páginas do Facebook. Dissertação (Mestrado em Ciência Política). Faculdade de Filosofia e Ciências Humanas, Universidade Federal de Minas Gerais, Belo Horizonte, 2015.

FRASER, N. Multiculturalism and gender equity: the U.S. "Difference" debates revisited. Constellations, v. 3, n. I, p. 6I-72, I996.

. From Distribution to recognition? Dilemmas of justice in a "postsocialist" age. In: . Justice interruptus - critical reflections on the "postsocialist" condition. London: Routledge, I997, p. II-39.

. Distorted beyond all recognition: a rejoinder to Axel Honneth. In: FRASER, N.; HONNETH, A. Redistribution or recognition? A political-philosophical exchange. Londres/Nova York: Verso, 2003, p. $198-236$.

. Social justice in the age of identity politics: redistribution, recognition, and participation. In: FRASER, N.; HONNETH, A. Redistribution or recognition? A political-philosophical exchange. Londres/ Nova York: Verso, 2003, p. 7-I09.

. Scales of justice: reimagining political space in a globalizing world. New York: Columbia University Press, 2008

FRIEDMAN, Debra; MCADAM, Doug. Collective identity and activism: networks, choices, and the life of a social movement. In: MORRIS, A. D.; MUELLER, C. M. C. Frontiers in social movement theory. New Haven/London: Yale University Press, I992, p. I56-I73.

GAMSON, William. Talking politics. Cambridge/Nova York/Melbourne: Cambridge University Press, I992, $272 \mathrm{p}$.

GAMSON, W. The social psychology of collective action. In: MORRIS, A. D.; MUELLER, C. M. C. Frontiers in social movement theory: New Haven/London: Yale University Press, I992, p. 53-76.

GARCÍA CANCLINI, N. Culturas híbridas: estratégias para entrar e sair da modernidade. São Paulo: Edusp, I997.

GERBAUDO, P. Protest avatars as memetic signifiers: political profile pictures and the construction of collective identity on social media in the $20 \mathrm{II}$ protest wave. Information, Communication \& Society, v. I8, n. 8, p. 9I6-929, 2015.

GERBAUDO, P.; TRERÉ, E. In search of the 'we' of social media activism: introduction to the special issue on social media and protest identities. Information, Communication e Society, v. I8, n. 8, p. 865-871, 2015.

GIDDENS, A. Modernidade e identidade. Rio de Janeiro: Jorge Zahar, 2002.

GILROY, P. The black Atlantic: modernity and double consciousness. Cambridge, Mass.: Harvard University Press, I993.

GUTMANN, A. Identity in democracy. Princeton, N. J.: Princeton University Press, 2003.

HALL, S. A identidade cultural na pós-modernidade. 9. ed. Rio de Janeiro: DP\&A, 2004.

HARDT, M.; NEGRI, A. Multidão: guerra e democracia na era do império. 4. ed. Rio de Janeiro: Record, 20I4. HONNETH, A. Luta por reconhecimento: a gramática moral dos conflitos sociais. São Paulo: Ed. 34, 2003, 29Iр. 
. Organized self-realization: some paradoxes of individualization. European Journal of Social Theory, v. 7, n. 4, p. 463-478, 2004 .

. The I in We: studies in the theory of recognition. Cambridge: Polity, 2012.

hooks, b. Ain't I a Woman?: black women and feminism. Boston: South End Press, I98I.

LACLAU, E; MOUFFE, C. Hegemony \& socialist strategy: towards a radical democratic politics. London; New York: Verso, I985.

MACHADO, S. Atores políticos em processo: a dinâmica identitária a partir das manifestações de 2013. Texto apresentado na XXIV Semana do Conhecimento da UFMG, Belo Horizonte, I9-20 de outubro de 2015 .

MAFRA, R. L. M. Entre o espetáculo, a festa e a argumentação: mídia, comunicação estratégica e mobilização social. Belo Horizonte: Autêntica, 2006.

MARKELL, P. Bound by recognition. Princeton: Princeton University Press, 2003.

MARTÍN-BARBERO, J. De los medios a las mediaciones: comunicación, cultura y hegemonía. Mexico: G. Gilli, I987.

MCADAM, D.; TARROW, S.; TILLY, C. Para mapear o confronto político. Lua Nova, n.76, p. II-48, 2009.

MELUCCI, A. Challenging codes: collective action in the information age. Cambridge: Cambridge University Press, I996.

MENDONÇA, R. F. Reconhecimento e deliberação: as lutas das pessoas atingidas pela hanseníase em diferentes âmbitos interacionais. 2009.369f. Tese (Doutorado). Programa de Pós-graduação em Comunicação Social, Universidade Federal de Minas Gerais, 2009.

. Democracia e desigualdade: as contribuições da teoria do reconhecimento. Revista Brasileira de Ciência Política, Brasília, n. 9, p. II9-I46, 2012.

. Reconhecimento. In: AVRITZER, L et al. (Org.). Dimensões políticas da justiça. Rio de Janeiro: Civilização Brasileira, 20I3, p. II7-I3I.

.What if the forms of recognition contradict each other? The case of the struggles of people affected by leprosy in Brazil. Constellations (Oxford. Print), v. 2I, p. 32-49, 2014.

et al. Understanding protests as "events" - the symbolic struggles in 2013 protests in Turkey and Brazil. Article prepared for the 20I6 IPSA meeting. Poznán, 23-28 July 2016.

; ERCAN, S. Deliberation and protest: strange bedfellows? Revealing the deliberative potential of 2013 protests in Turkey and Brazil. Policy Studies, v. 36, n. 3, p. 267-282, 2015.

MILAN, S. From social movements to cloud protesting: the evolution of collective identity. Information, Communication e Society, v. I8, n. 8, p. 887-900, 2015.

MONTERDE, A. et al. Multitudinous identities: a qualitative and network analysis of the ${ }_{5} \mathrm{M}$ collective identity. Information, Communication er Society, v. I8, n. 8, p. 930-950, 2015.

OLSON, M. A lógica da ação coletiva: os benefícios públicos e uma teoria dos grupos sociais. São Paulo: Edusp, I999.

PIVEN, F. F; CLOWARD, R. A. Collective protest: a critique of resource-mobilization theory. In: LYMAN, S. (Ed.). Social movements. Critiques, concepts, case-studies. New York: New York University Press, I995.

RICCI, R.; ARLEY, P. Nas ruas: a outra política que emergiu em junho de 20I3. Belo Horizonte: Letramento, 2014 .

SARMENTO, R.; REIS, S.; MENDONÇA, R. F. As jornadas de junho e a questão de gênero: as idas e vindas das lutas por justiça. Revista Brasileira de Ciência Política, n, 22, p. 93-I28, 2017.

SIBILIA, P. O show do eu: a intimidade como espetáculo. Rio de Janeiro: Nova Fronteira, 2008.

SNOW, D. Identity dilemmas, discursive fields, identity work, and mobilization: clarifying the identitymovement nexus. In: STEKELENBURG, Jacquelien van; ROGGEBAND, Conny; KLANDERMANS, 
Bert. The future of social movement research: dynamics, mechanisms, and processes. University of Minnesota Press, p. 263-280, 2013.

SPIVAK, G. In other worlds: essays in cultural politics. New York: Routledge, I988. . Pode o subalterno falar?. Belo Horizonte: Editora UFMG, 2010.

TARROW, S. The language of contention - revolutions in words, I688-20I2. Cambridge: University of Cambridge, 2013.

TAYLOR, C. The politics of recognition. In: GUTMANN, Amy (Ed.) Multiculturalism: examining the politics of recognition. Princeton: Princeton University Press, p. 25-73, I994.

. Sources of the self: the making of the modern identity. Cambridge: Harvard University Press, I989

TAYLOR, V. Social movement participation in the global society: identity, networks, and emotions. In: STEKELENBURG, Jacquelien van; ROGGEBAND, Conny; KLANDERMANS, Bert. The future of social movement research: dynamics, mechanisms, and processes. University of Minnesota Press, p. 37-57, 2013. YOUNG, I. Justice and the politics of difference. Princeton: Princeton University Press, I990. 